Review

\title{
Vulvar and Vaginal Melanomas-The Darker Shades of Gynecological Cancers
}

\author{
Elena-Codruța Dobrică ${ }^{1,2, \dagger}$, Cristina Vâjâitu ${ }^{2,3, \dagger}$, Carmen Elena Condrat ${ }^{4}$, Dragoș Crețoiu ${ }^{4,5}$, Ileana Popa ${ }^{6}$, \\ Bogdan Severus Gaspar ${ }^{7,8}$, Nicolae Suciu ${ }^{4,9}$, Sanda Maria Crețoiu ${ }^{5, *}$ (1) and Valentin Nicolae Varlas ${ }^{10,11}$ (i)
}

1 Department of Pathophysiology, University of Medicine and Pharmacy of Craiova, 200349 Craiova, Romania; codrutadobrica@gmail.com

2 Department of Dermatology and Allergology, “Elias" Emergency University Hospital, 011461 Bucharest, Romania; cristina.vajaitu@gmail.com

3 Dermatology Department, Carol Davila University of Medicine and Pharmacy, 050474 Bucharest, Romania

4 Alessandrescu-Rusescu National Institute for Mother and Child Health, Fetal Medicine Excellence Research Center, 11062 Bucharest, Romania; drcarmencondrat@gmail.com (C.E.C.); dragos.cretoiu@umfcd.ro (D.C.); nsuciu54@yahoo.com (N.S.)

5 Department of Cell and Molecular Biology and Histology, Carol Davila University of Medicine and Pharmacy, 050474 Bucharest, Romania

6 Department of Anatomopathology, Coltea Clinical Hospital, 030167 Bucharest, Romania; ileanapopa2004@gmail.com

7 Surgery Department, Carol Davila University of Medicine and Pharmacy, 050474 Bucharest, Romania; bogdan.gaspar@umfcd.ro

8 Surgery Clinic, Bucharest Emergency Clinical Hospital, 014461 Bucharest, Romania

9 Division of Obstetrics, Gynecology and Neonatology, Carol Davila University of Medicine and Pharmacy, 050474 Bucharest, Romania

check for

updates

Citation: Dobrică, E.-C.; Vâjâitu, C.; Condrat, C.E.; Crețoiu, D.; Popa, I.;

Gaspar, B.S.; Suciu, N.; Crețoiu, S.M.;

Varlas, V.N. Vulvar and Vaginal

Melanomas-The Darker Shades of

Gynecological Cancers. Biomedicines

2021, 9, 758. https://doi.org/

10.3390/biomedicines 9070758

Academic Editor: Naomi Nakayama

Received: 30 April 2021

Accepted: 23 June 2021

Published: 30 June 2021

Publisher's Note: MDPI stays neutral with regard to jurisdictional claims in published maps and institutional affiliations.

Copyright: (c) 2021 by the authors. Licensee MDPI, Basel, Switzerland. This article is an open access article distributed under the terms and conditions of the Creative Commons Attribution (CC BY) license (https:/ / creativecommons.org/licenses/by/ $4.0 /)$.
10 Department of Obstetrics and Gynecology, Filantropia Clinical Hospital, 011132 Bucharest, Romania; valentin.varlas@umfcd.ro

11 Faculty of Dental Medicine, Carol Davila University of Medicine and Pharmacy, 050474 Bucharest, Romania

* Correspondence: sanda@cretoiu.ro

+ Equal contribution to this paper.

Abstract: Melanomas of the skin are poorly circumscribed lesions, very frequently asymptomatic but unfortunately with a continuous growing incidence. In this landscape, one can distinguish melanomas originating in the mucous membranes and located in areas not exposed to the sun, namely the vulvo-vaginal melanomas. By contrast with cutaneous melanomas, the incidence of these types of melanomas is constant, being diagnosed in females in their late sixties. While hairy skin and glabrous skin melanomas of the vulva account for $5 \%$ of all cancers located in the vulva, melanomas of the vagina and urethra are particularly rare conditions. The location in areas less accessible to periodic inspection determines their diagnosis in advanced stages, often metastatic. Moreover, despite the large number of drugs newly approved in recent decades for the treatment of cutaneous melanoma, especially in the category of biological drugs, the mortality of vulvo-vaginal melanomas has remained almost constant. This, together with the absence of specific treatment guidelines due to the lack of a sufficient number of cases to conduct randomized clinical trials, makes melanomas with this localization a discouraging diagnosis, associated with a very poor prognosis. Our aim is therefore to draw attention to this oftentimes overlooked entity in order to encourage the community to employ various strategies meant to increase research in this area. By highlighting the main risk factors of vulvar and vaginal melanomas, as well as the clinical manifestations and molecular changes underlying these neoplasms, ideally novel therapeutic schemes will, in time, be brought into effect.

Keywords: vulvar melanoma; vaginal melanoma; targeted therapy; gynecological cancer; melanoma treatment 


\section{Introduction}

Melanoma is an extremely aggressive tumor with a high metastatic rate, whose diagnosis in advanced stages was associated, until a decade ago, with minimal chances of survival [1]. It is a tumor originating in melanocyte cells which are formed during embryogenesis from the neural crest of the trunk [2]. Melanocytes come from progenitor cells with a high migration capacity. This migratory capacity explains why they are distributed and present at the level of a large number of structures: the skin - the basal layer of the epidermis (with an important role in the uniform pigmentation by forming epidermal-melanin units) — the inner ear, gastrointestinal tract and the nerve structures [3]. The incidence of melanoma has seen a spectacular increase in the last two decades, with over 300,000 new cases in 2018, the most affected countries being Australia and New Zealand (over 33 cases /100,000 inhabitants), the average age of onset of melanoma being 65 years old $[4,5]$. Regarding the distribution according to sex, in the case of melanomas discovered in adulthood, there is a predominance of cases in males, with a reversal of the phenomenon for melanomas diagnosed between $15-39$ years, over $60 \%$ of cases appearing in the female population [6,7]. An interesting phenomenon was observed in the young population diagnosed with melanoma, the cases experiencing an alarming increase between 1999-2006, with a decrease in the next 10 years, dynamics overlapping with the increasing popularity of photoprotection methods and awareness of the danger posed by tanning beds exposure $[6,8]$. Due to the poorly associated prognosis determined mainly by the discovery of melanoma in advanced stages, melanoma remains the skin cancer with the highest mortality, the 5-year survival rate being less than $80 \%$ and depending on the degree of local tumor extension, lymphatic invasion, and presence of metastases [9,10]. Although dermatoscopic evaluation has become essential in pigmentary lesions screening, the diagnosis of melanoma is difficult even for experienced dermatologists, the clinical and dermatoscopic appearance presenting a great variability and sometimes even possessing misleading histological aspects that can lead to false-negative results $[9,11,12]$.

Melanomas with genital location are included in the category of rare neoplasms, vulvar and vaginal melanomas totaling less than $1-2 \%$ of all melanomas diagnosed in females $[13,14]$. Vulvar melanoma represents approximately $5 \%$ of all cancers located in the vulva, being more common in adulthood (average age is 68 years) $[15,16]$. Between 2.5 and 4.5 patients $/ 100,000$ inhabitants are affected each year by vulvar cancer, melanoma with this location being among the top four most common vulvar cancers, the most frequent being squamous cell carcinoma (over $75 \%$ of cases versus $5.6 \%$ for melanoma) $[17,18]$.

On the other hand, vaginal melanoma is even a rarer condition, accounting for less than $0.05-0.1 \%$ of genital neoplasms [19]. The average age of onset is lower than in the case of vulvar melanoma (57 years), and the prognosis is much worse, less than a third of patients surviving 5 years after diagnosis, despite the correct instituted treatment [20]. In a study performed on 1400 patients with vulvar melanoma and 463 with vaginal melanoma, Wohlmuth et al. highlight the occurrence of the former at a significantly younger age $(p<0.001)[21]$.

Unlike cutaneous melanoma, which is much more common in Caucasians, the frequency of vulvar and vaginal melanomas has very little variability related to race, but there is a slight increase in frequency in Whites (3.14 vs. 1.02: 1) [22]. This increase is statistically significant for vulvar melanoma, but not for those with vaginal localization $(p<0.001)$ [21].

Particular attention has been paid in the last years to the necessity of avoiding sun exposure using screen protective agents, periodic self-examination of pigmented lesions and periodic dermatoscopic surveillance of potentially evolving lesions, these being considered the most important methods to decrease the incidence and mortality of melanoma [23]. However, the genital area is often overlooked as a possible site of melanoma and other skin cancers, both by patients and doctors. Yet, melanoma with localization in the vulva and vagina is characterized by increased severity especially due to late diagnosis, most often in metastatic stages [18]. Moreover, the therapeutic means used in cutaneous melanomas are of little use in the treatment of melanomas with vulvar and vaginal localization, mortality 
having high values and not changing considerably in the last three decades (5-year survival rates vary between $10 \%$ and $63 \%$ ) $[17,24-26]$. Thus, the present review aims to highlight the main risk factors identified in the occurrence of vulvar and vaginal melanomas, clinical manifestations, molecular changes underlying these neoplasms, as well as the main therapeutic means and their effectiveness in terms of survival.

\section{Risk Factors}

Melanoma, like most neoplastic pathologies, is a multifactorial disease, its occurrence being related to interactions between environmental and host factors, thus appearing as a consequence of genetic and epigenetic modifications that eventually lead to alteration of regulatory processes [27]. Although a number of risk factors involved in the etiopathogenesis of the disease have been identified for cutaneous melanoma, such as intermittent exposure with increased intensity to ultraviolet (UV) radiation, history of sunburns (more common at high latitudes), the presence of atypical nevi, specific skin phenotype (lightly pigmented skin, with light eyes, blond or reddish hair, presence of freckles), family history with specific genetic changes that alter the ultraviolets repair of melanocytes subjected to UV radiation, the use of Psoralen and Ultraviolet A therapy (PUVA) for a long time (over 15 years after exposure), the etiopathogenic mechanisms for vulvar and vaginal melanomas are not yet elucidated, and no specific factors involved in their occurrence have been identified [17,28-32]. Moreover, in a study published by Heinzelmann-Schwartzet et al., the onset of vulvar melanoma was regarded as spontaneous, de novo, with changes in a single melanocyte cell being enough to trigger the process of oncogenesis and determine the formation of melanoma [17].

However, there are studies that show a greater association between mucosal melanomas in general, and vaginal and vulvar melanomas in particular, and certain factors:

Sex. The female gender appears to be a risk factor for mucosal melanomas in general, which are twice as common as in men, compared to cutaneous melanomas whose distribution is similar between the two sexes [33].

Age. Vulvar melanoma is a disease that has an average age of onset of 68 years old, the risk of onset increasing with age (the number of cases increases from $0.11 / 1$ million inhabitants for 15-29 years range, to 3.5/1 million inhabitants for those over 60 years old $[34,35])$. In contrast, cutaneous melanoma has a maximum incidence around the fourth decade of life [35].

Family history of cutaneous melanoma appears to be a risk factor for vulvar melanoma [36].

Ethnicity also seems to play an important role in the evolution of melanomas with genital localization and in their prognosis. Even if the association is not as strong as in the case of cutaneous melanomas, vulvar and vaginal melanomas are three times more common in the white race $(p<0.001)$ [22]. However, the prognosis has an inverse association, the mortality being much higher among the African population [37].

Lichen sclerosus is a precursor lesion of squamous cell carcinoma of the genital area which appears in its evolution in a percentage of approximately $5 \%$, the causal link between the two pathologies being well known. Regarding the occurrence of vulvar melanoma in patients with lichen sclerosus, while a causal link has not been clearly established, although the number of reported cases is quite small, an increased incidence of vulvar melanoma has been observed among these patients (relative risk $=341$ ) $[38,39]$.

UV radiation. Though vulvar melanoma does not occur in photo-exposed areas, some studies suggest the indirect involvement of $U V$ radiation in the pathogenesis of vulvar melanoma, through alterations of the immune response that favor modifications of the pathways involved in oncogenesis. However, it is important to note that the role of radiation in the pathogenesis of the disease is significantly lower than in skin melanoma [34].

Although the Human Papilloma Virus (HPV) is known for its roles in the development of benign (condyloma acuminata) and malignant tumors (invasive squamous cell carcinoma, anorectal cancers, penile cancers, squamous vaginal cancers) with genital local- 
ization, there is yet no mechanism to demonstrate its involvement in melanoma. There is no evidence that the HPV infection elevates the risk of vulvar or vaginal melanomas [32,40-42].

\section{Clinical Manifestations}

Unlike cutaneous melanoma which is most frequently distributed on photo-exposed areas (face, trunk, lower limbs) making it possible to diagnose it from early stages, vulvar and vaginal melanomas have origins that are generally overlooked by frequent inspection, the anatomical position of the lesion being the main reason for its late diagnosis and poor prognosis [43]. Melanomas of the vulvar region can occur in a variety of sites starting from the hairy skin of the labium majus to the introitus (Figure 1). The most common sites are the clitoris, the labia majora, and the labia minora, and in most cases, multiple tumors can be detected $[34,44,45]$.

Vulvar and vaginal melanomas are pigmented lesions with variable diameters (generally over $7 \mathrm{~mm}$ ), with macular (most frequently), papular or nodular appearance, most often asymmetrical and with an inhomogeneous appearance in terms of pigmentation $[44,46,47]$. There are also reports in the literature of cases with amelanotic manifestations of genital melanomas, especially at the vaginal level [20,48]. The first case of genital melanoma was described in 1861 in a 35-year-old patient who presented with multiple pigmentary lesions and evolved with neurological and digestive symptoms in the context of multiple secondary determinations and, subsequently, exitus [49]. Since then, multiple cases of vulvar and vaginal melanomas with various clinical, dermatoscopic aspects, and symptoms have been depicted in the literature (for additional details see $[16,20]$ ).

As it is a rare pathology, most of the clinical data presented in the literature are obtained from isolated case presentations or case series, most of which highlight the presence of genital bleeding, a palpable, white-gray color mass, itching, dyspareunia, yellow genital secretions, and local pain [50-54]. Cases that mention the presence of painless masses are also reported [55]. Most of the cases presented depict the tumor in the labia minora. The diagnosis is generally late, with half of the patients being diagnosed in advanced stages, with the invasion of deep structures [56].

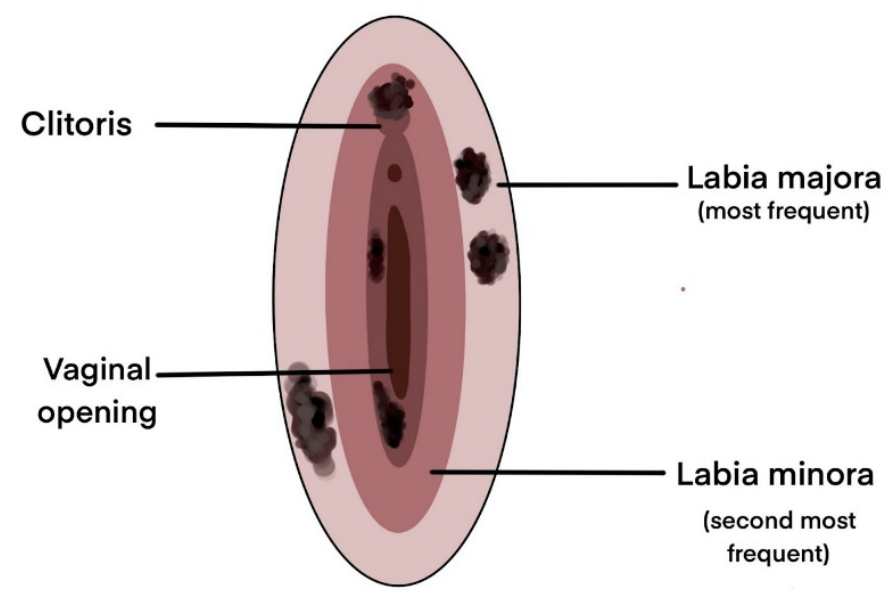

Figure 1. Most common sites for vulvar melanomas [15,36,47,57-59].

Although not so numerous and generally on small patient samples, there are prospective or retrospective clinical studies and meta-analyses that have highlighted the main clinical manifestations and the most common sites of vulvar and vaginal melanomas, which are further illustrated in Table 1.

Regarding the dermatoscopic examination, it is characterized by asymmetrical, irregular aspects, both in terms of contour and pigmentation, lacking a clear structure. In addition, multiple cases report the presence of blue-gray or white-gray areas and globular punctiform black-brown structures $[45,58]$. 
Table 1. Clinical findings in melanoma of the vulva and vagina $[15,26,36,47,57-60]$.

\begin{tabular}{cccc}
\hline $\begin{array}{c}\text { Number } \\
\text { of Patients }\end{array}$ & $\begin{array}{c}\text { Tumor } \\
\text { Localisation }\end{array}$ & $\begin{array}{c}\text { Main Signs } \\
\text { and Symptoms }\end{array}$ & $\begin{array}{c}\text { Others Signs } \\
\text { and Symptoms }\end{array}$ \\
\hline 51 & Labia minora & $\begin{array}{c}\text { Pain, Palpable mass, Genital } \\
\text { bleeding, Pruritus }\end{array}$ & Dysuria, Ulceration \\
\hline 20 & Labia majora & $\begin{array}{c}\text { Genital bleeding, Pruritus, } \\
\text { Palpable mass }\end{array}$ & $\begin{array}{c}\text { Pain, Dysuria, Unhealing sore, } \\
\text { Urinary difficulties }\end{array}$ \\
\hline 10 & Labia majora & Pruritus & - \\
\hline 11 & Not specified & Pruritus, Pain, Genital bleeding & - \\
\hline 14 & Labia minora & Pruritus & [36] \\
\hline 31 & Vagina & $\begin{array}{c}\text { Genital bleeding, Pain, } \\
\text { Palpable mass }\end{array}$ & $\begin{array}{c}\text { Abnormal vaginal secretion, } \\
\text { Urinary difficulties }\end{array}$ \\
\hline 33 & Not specified & $\begin{array}{c}\text { Palpable mass, Genital bleeding, } \\
\text { Pain, Pruritus }\end{array}$ & $\begin{array}{c}\text { Abnormal vaginal secretion, } \\
\text { Dysuria, Dyspareunia, Ulceration }\end{array}$ \\
\hline 198 & Unilateral, & [60] & [59] \\
\hline
\end{tabular}

\section{Histological Aspects}

Melanoma may arise de novo or within an existing benign or dysplastic nevus. Lesions usually measure between 2-4 mm in thickness and are frequently ulcerated. In addition to this clinical aspect that raises the suspicion of a malignant lesion, histopathological examination is absolutely necessary to establish the diagnosis.

\subsection{Macroscopic Examination}

The distribution of melanomas on the skin can be at any level, therefore areas not exposed to the sun should not be neglected, which is practically the case of vulvar melanomas. Considering that vulvar melanomas often appear in older women, they should be advised to self-examine with a hand-held mirror [13]. The first step in examining pigmented nevi, moles, and brown spots and growths is to apply the ABCDEs rule and the Ugly Duckling sign (although not applicable for vulvar melanomas) [61]. As for the rest of the skin, vulvar melanomas are black or dark brown, but may also vary from white, pink, red, to other colors $[13,62,63]$.

The ABCDE rule refers to the main macroscopical aspects taken into consideration when assessing cutaneous lesions, namely Asymmetry (the two halves of the mole are not identical), Border irregularity (edges are ragged or notched), Color variation (shades of tan, brown, or black and sometimes patches of red, blue, or white), Diameter ( $>6 \mathrm{~mm}$ or $>1 / 4$ inch) or Dermoscopic structure, and Evolution (Figure 2) [64]. The same rule can be regarded from a histological point of view, thus becoming the $\mathrm{ABCDE}(\mathrm{FG})$ rule, which refers to Asymmetry (silhouette and color imbalance), Buckshot scatter (pagetoid distribution), Cytological atypia, Deep mitosis, Enclosing lymphocytes, Fibrosis, and Gainsaying (=no) maturation [65].

Another step in the diagnosis of vulvar melanoma is dermoscopy, which facilitates early detection based on the identification of a lesion with irregular dots, multiple colors (black, blue, brown, pink, gray, and white), a blue-white veil, and atypical vessels [66]. When the lesion is assessed and determined as suspicious, the next step is to determine the most important factor for the future evolution and prognosis- the vertical depth of invasion [67]. Therefore, the most effective way to assess the local invasion is the sampling of the lesion. The evolution of melanoma depends on the correctness and accuracy of the biopsy technique. Thus, two types of biopsies of suspicious formations are described: an excisional biopsy that removes the entire lesion, and an incisional biopsy, which removes only a portion from the suspicious cutaneous lesion [68]. Excision biopsy is considered the 
gold standard in the correct diagnosis of melanomas, and has the advantage of providing accurate microstaging [69].

\begin{tabular}{|c|c|c|c|c|}
\hline & Benign & & Malignant & \\
\hline symmetrical & & Asymmetry & & $\begin{array}{c}\text { two non- identical } \\
\text { halves }\end{array}$ \\
\hline $\begin{array}{l}\text { round/oval } \\
\text { regular edges }\end{array}$ & & Border & & $\begin{array}{l}\text { irregular ragged or } \\
\text { blurred edges }\end{array}$ \\
\hline brown, uniform & & lour & & $\begin{array}{l}\text { different shades } \\
\text { from brown-black to } \\
\text { red-white }\end{array}$ \\
\hline spot $<6 \mathrm{~mm}$ & & iameter & & spot $>6 \mathrm{~mm}$ \\
\hline $\begin{array}{l}\text { no evolution } \\
\text { in time }\end{array}$ & & & & $\begin{array}{l}\text { evolving in size, } \\
\text { colour, contour }\end{array}$ \\
\hline
\end{tabular}

Figure 2. ABCDE evaluation of a pigmentary skin lesion [64].

The 7th edition of The American Joint Committee on Cancer (AJCC) Cancer Staging Manual published in 2009 was the first to give up the Clark score, which was largely based on the level of anatomical invasion in the skin layers [70]. Further on, the 8th AJCC edition on melanoma staging and classification relies on the Breslow thickness in order to establish the depth of invasion, so as to accurately assign a stage based on the classical tumor, node, metastasis (TNM) scores [71]. Additionally, this latest edition specifies that tumor depth should be measured to the nearest $0.1 \mathrm{~mm}$ instead of $0.01 \mathrm{~mm}$, in order to improve precision [72]. Although there is not yet a standardized and unanimously accepted staging of vuvar melanomas, the Gynecologic Oncology Group (GOG) recommends the use of the AJCC staging manual instead of the International Federation of Gynecology and Obstetrics (FIGO) system, in spite of the several uncertainties that still persist [18]. Specifically, while generally regarded as mucosal tumors, the molecular characteristics of vulvar melanomas differ from those of both cutaneous and mucosal melanomas in terms of mutational signatures, thus prompting some authors to consider them a unique subclass $[21,73]$.

\subsection{Microscopic Examination}

From a cytological point of view, melanoma cells are of two types: epithelioid and spindle cells. The epithelioid type is characterized by large, round cells with abundant eosinophilic cytoplasm. They have vesicular nuclei with coarse irregular chromatin with peripheral condensation (pattern known as "peppered moth" nuclei). This cell type is most commonly found in nodular and superficial spreading melanomas. The stromal compartment is accompanied by a variable inflammatory infiltrate (brisk, non-brisk, absent), irregular distribution of the pigment, and dermal fibrosis.

\subsection{Histological Subtypes of Melanoma}

The class of tumors known as melanoma contains numerous histological subtypes that are not often considered of the utmost importance to clinicians or patients, especially in terms of prognosis [74]. Histopathological characteristics of the gynecological melanomas should be interpreted in the context of other clinical diagnostic criteria and macroscopic data. 
Superficial spreading melanoma (SSM) is the most common subtype, characterized by asymmetrical proliferation of atypical melanocytes. Individual melanocyte units are distributed at the dermo-epidermal junction and are characterized by the presence of large pagetoid areas $\left(>0.5 \mathrm{~mm}^{2}\right)$ [75].

Lentigo maligna melanoma (LMM) is characteristic for elderly patients repeatedly exposed to chronic sun damage. Melanocytes arranged in solitary units along the dermoepidermal junction are organized in small nests (lentiginous pattern), sometimes the nests being horizontally confluent and variable in size and shape (nevoid/dysplastic-like pattern). Dermal invasion of atypical melanocytes is frequent, as well as the extension into the hair follicles [76].

Acral lentiginous melanoma (ALM) is more common in the Afro-Asian population, on palms and soles, and involves the eccrine glands excretory ducts [77].

Nodular melanoma (NM) is considered the most aggressive form, and grows in depth rather than in diameter, so that the $\mathrm{ABCDE}$ rule does not apply [78]. It is characterized by a nodular dermal proliferation of atypical melanocytes.

Regarding vulvar melanomas, a retrospective study based on 43 patients, performed by DeMatos et al., showed that most of the mucosal melanoma lesions (vulvar, vaginal, and cervical) were not classified $(33 \%)$, while the rest were acral lentiginous $(30 \%)$, or superficial spreading melanoma (26\%). Unclassified tumors were either nodular or polypoid melanoma [79].

The most common vulvar melanomas subtypes are mucosal lentiginous and nodular melanoma. The characteristic microscopic aspects are represented by impairment of the epidermis, pagetoid spread of melanocytes, or melanocytes organized in nests (Figures 3 and 4) [80]. Usually, melanocytes are variable in size and shape, and are sometimes localized within lymphovascular spaces. Furthermore, they can frequently become confluent and lack maturation, showing atypical mitoses and increased apoptotic activity (Figures 5 and 6) [81]. The presence of an ulcerated tumor is associated with a poor prognosis.

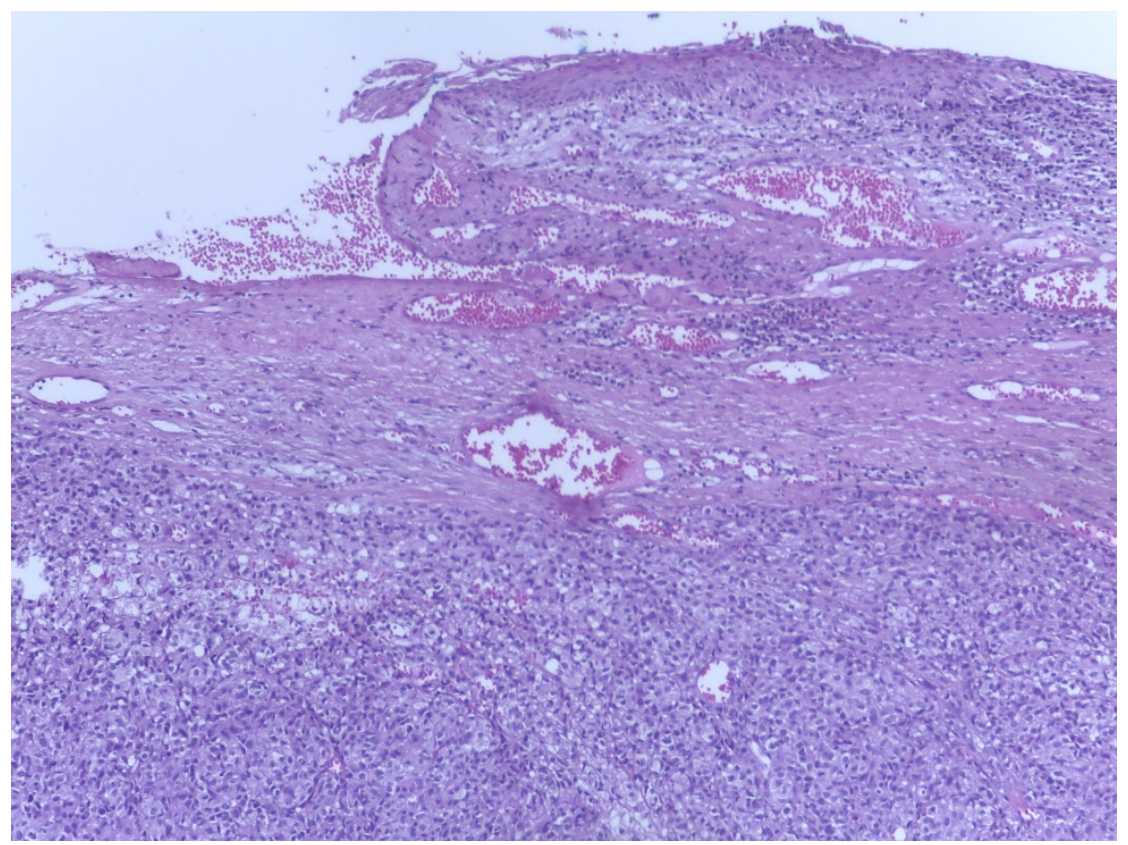

Figure 3. Vaginal melanoma. Vaginal squamous epithelium with areas of ulceration. In lamina propria one can observe tumoral cells organized in nests. Hematoxylin-eosin stain, original magnification $\times 4$ (histological image courtesy of dr. Ileana Popa). 

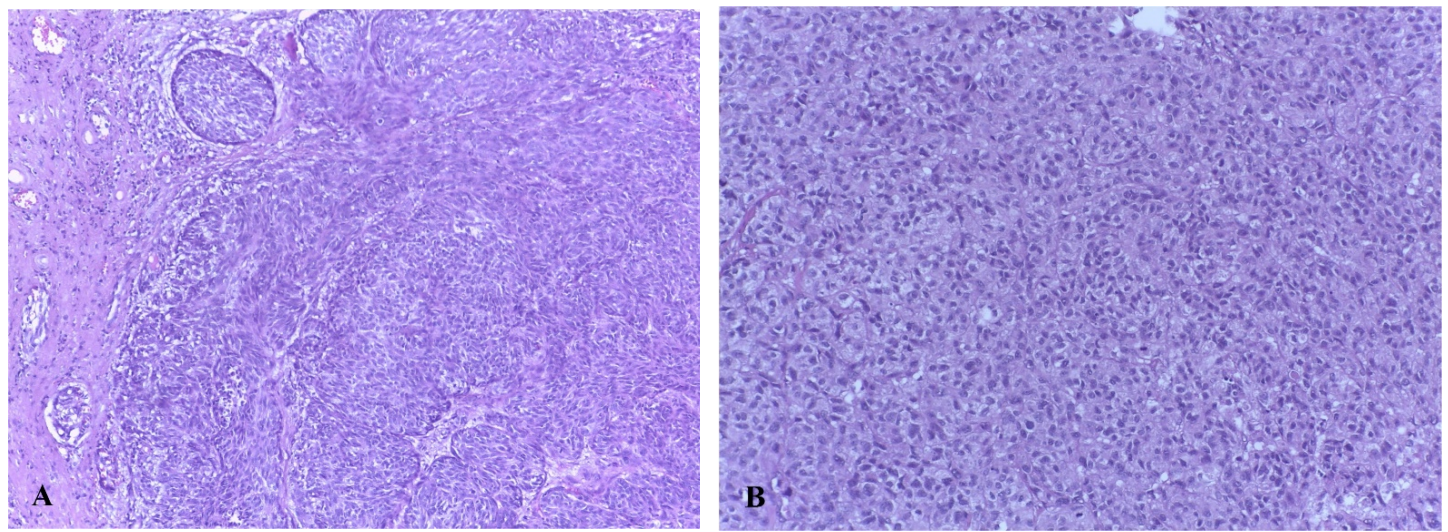

Figure 4. (A) Vaginal melanoma. Tumor cells organized in nests, some fusiform-looking cells (Hematoxylin-eosin stain, original magnification $\times 10$.) (B) Vaginal melanoma. Epithelioid-looking malignant cells in lamina propria outlooking a nest disposition, abundant eosinophilic cytoplasm. Hematoxylin-eosin stain, original magnification $\times 20$ (histological image courtesy of dr. Ileana Popa).
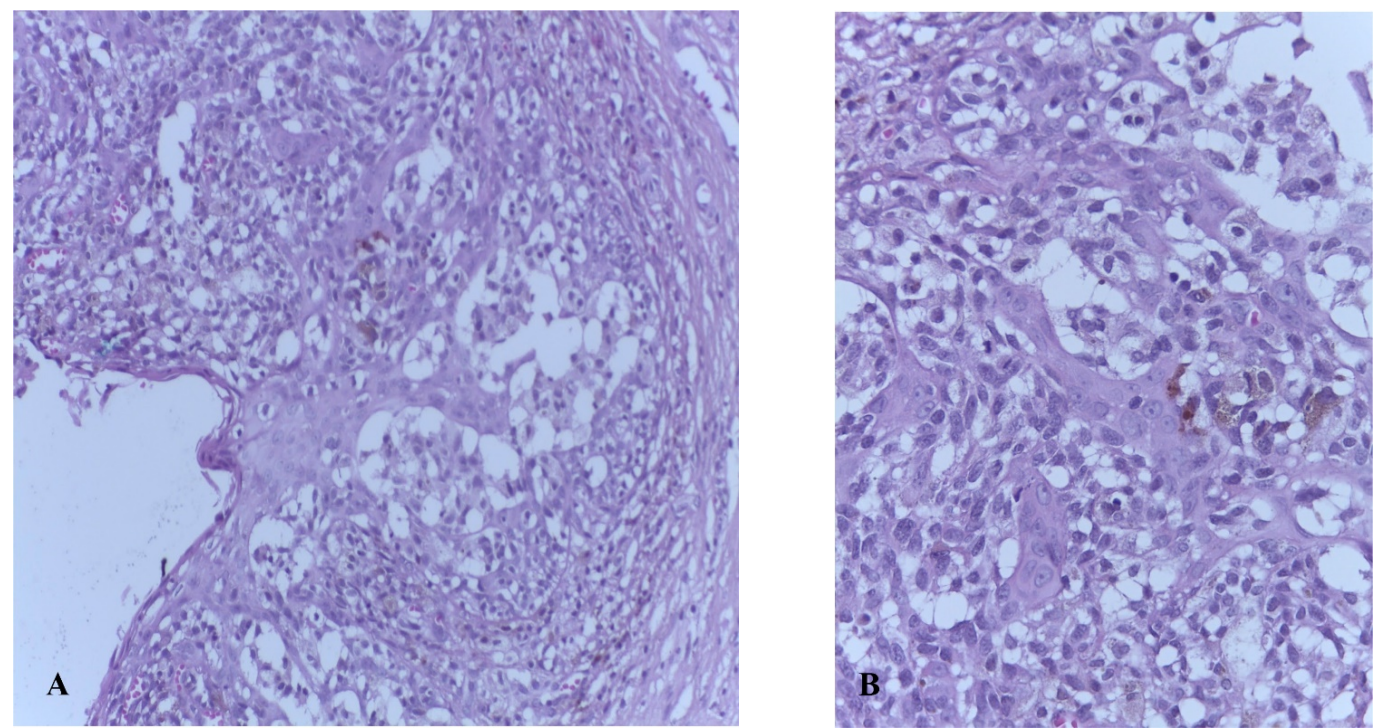

Figure 5. (A) Vaginal melanoma. Tumoral cells filled with melanin organized in nests at the epithelium-lamina propria junctionpathognomonic for the diagnosis, original magnification $\times 20$. (B) Detail showing haphazardly distributed atypical melanocytes in lamina propria original magnification $\times 40$ Hematoxylin-eosin stain (histological image courtesy of dr. Ileana Popa).
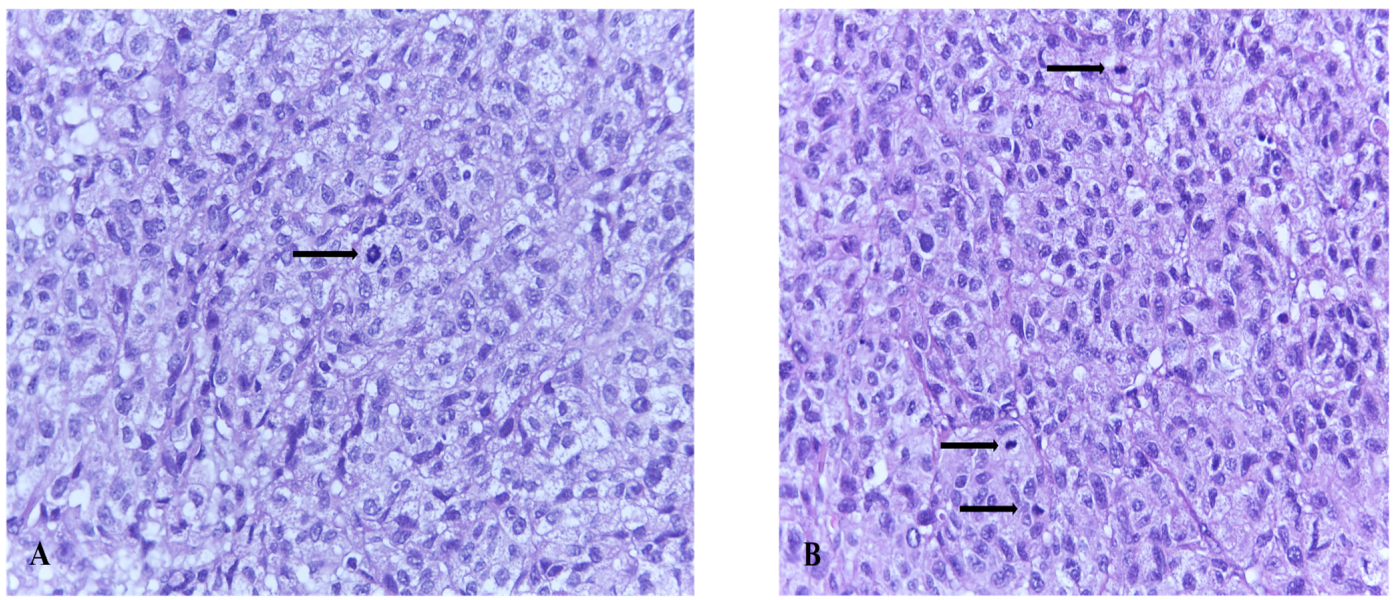

Figure 6. (A,B) Vaginal melanoma. Arrows-Nuclear mitoses-original magnification $\times 40$.Hematoxylin-eosin stain (histological image courtesy of dr. Ileana Popa). 


\section{Immuno(cyto)histochemistry in the Diagnosis of Melanoma}

The criteria described above are imperiled by subjective interpretations, lacking objectivity, and reproducibility. Moreover, melanomas are able to mimic a lot of other malignancies with epithelial, hematologic, mesenchymal, and neural origin, such as lymphomas, carcinomas, neuroendocrine tumors, and sarcomas [82]. Therefore, immunocytochemistry (IHC) is a step most often necessary in the correct evaluation of a melanocytic suspect lesion in patients with underlying hematological pathologies or with solid cancers with frequent skin metastasis. Immunohistochemistry can show its utility in the differential diagnosis of vulvar soft tissue lesions, i.e., Paget disease, which can mimic melanoma [83]. In addition, IHC is less expensive by comparison with electron microscopy, which can bring additional information for melanoma cells containing melanosomes and other ultrastructural particularities which are not present in Paget disease.

Melanomas are usually immunoreactive for Melanoma antigen recognized by T-cells-1 (MART-1) or melan A, S-100 protein, melanoma-specific antigen (HMB-45), tyrosinase, and Microphthalmia transcription factor (MITF) [84].

S-100 protein, a sensitive marker for melanocytic differentiation, is considered to have a sensitivity of $97-100 \%$, but the specificity for melanoma is low since is also expressed on glial cells, Schwann cells, chondrocytes, lipocytes, dendritic cells, histiocytes [85].

One of the first specific markers that was discovered is HMB45, a marker of the cytoplasmic pre melanosomal glycoprotein gp100 [86].

Melan A is the most widely used technique for identifying basal melanocytic proliferations, having a more intense and diffuse staining than HMB45 and a specificity of 95-100\% [87].

Further on, the Sry-related HMg-Box gene 10 (SOX10) nuclear transcription factor is a key player in the differentiation of pluripotent neural crest cells into melanocytes. In this regard, its use as a metastatic melanoma marker has been investigated and found to be highly specific and sensitive [88].

\section{Molecular Characterization}

The pathogenesis of genital tract melanomas can mimic that of cutaneous melanoma developed in areas that are sun-protected, as in the case of vulvar melanomas. Moreover, other types of mucosal melanomas (e.g., the respiratory and the gastrointestinal tract) can serve as a model for the development of vaginal or cervical melanomas. Still, there are gaps in understanding the pathogenesis of vulvar or vaginal melanomas. However, elucidating the pathways involved in melanoma genesis is a very important step towards future advanced precision treatment.

Mucosal melanomas represent a challenge in relation to treatment, since, as opposed to cutaneous melanomas, not only are they detected in more advanced stages, but they are also less responsive to immunotherapy and lack activating mutations involving dominant MAP kinases $[89,90]$. Mutations in KIT, NF1 and SF3B1 genes are more frequently seen in mucosal melanomas, while alterations to NRAS and BRAF genes are more common in cutaneous melanomas [91,92]. Female genital tract melanomas can sometimes contradict the pattern described above. A study involving the whole-genome analysis of 284 patients diagnosed with mucosal melanoma localized in different sites revealed 10 mutated genes (Table 2) [93].

A retrospective study performed by Rouzbachman et al. on 33 vulvar and 11 vaginal malignant melanomas identified by next-generation sequencing analysis, found that the most frequent mutations were in C-KIT and NRAS genes, while BRAF mutations were infrequent. The study did not establish a correlation with the prognosis or outcome for these patients [94].

A more recent study performed by Cai et al. on 19 melanomas of the female genital tract and paired with 25 cutaneous melanomas, 18 acral melanomas and 11 melanomas of the nasal cavity, concluded that malignant melanoma of the female genital tract harbors distinct mutation rates in the KIT, BRAF, SF3B1, KRAS, and NRAS genes. Moreover, this 
location of the melanoma is an entirely distinct entity from skin melanoma and melanomas of the nasal cavity, while cervix melanomas also have some particularities, and do not suffer recurrent KIT mutations, or mutations of the NRAS and SF3B1 genes [95].

Because BRAF and NRAS mutations are uncommon in non-cutaneous melanomas, we can consider that each melanoma subtype depends on a different oncogenetic pathway for its development. This leads to the idea that it will not benefit from anti-RAF treatment, although large studies are needed before considering this as a rule. However, in the era of precision medicine, the importance of driver mutations cannot be neglected, and should become part of mucosal melanoma routine clinical testing [96].

Table 2. The main mutations that occur in melanomas and their frequency of occurrence [93,97-102].

\begin{tabular}{|c|c|c|}
\hline Mutated Gene & Percentage of Mutation (\%) & Details \\
\hline NRAS & $12 / 67-17.9 \%$ & $\begin{array}{l}\text { - } \quad \text { codon } 61 \text {-less involved in mucosal melanomas } \\
\text { - } \quad \text { codon } 12-\text { more involved in mucosal melanomas } \\
\text { - more frequent in case of metastatic or recurrent melanoma [93] }\end{array}$ \\
\hline BRAF & $11 / 67-16.4 \%$ & $\begin{array}{l}\text { - } \quad \text { mostly mutations in protein tyrosine kinase domain } \\
\text { predominant targeting the hotspot region between amino-acids } \\
594 \text { and } 600 \text { [93] }\end{array}$ \\
\hline NF1 & $11 / 67-16.4 \%$ & $\begin{array}{l}\text { - are correlated with melanomas developed on high UV exposure } \\
\text { areas [97] } \\
\text { NF-1 mutation melanomas are more frequently involving female } \\
\text { patients, have a higher Breslow score, and can be associated with } \\
\text { subsequent neoplasia [98] }\end{array}$ \\
\hline KIT & $10 / 67-14.9 \%$ & $\begin{array}{l}\text { - } \quad \text { are frequently screened for mutations in exons } 9,11,13,17 \text {, and } 18 \\
\text { KIT mutations are more frequently involved in vulvar melanoma } \\
\text { than in other types of mucosal melanomas } \\
\text { single substitutions of an amino acid are the most frequent KIT } \\
\text { mutations, the most common being L576P [99] }\end{array}$ \\
\hline SF3B1 & $8 / 67-11.9 \%$ & $\begin{array}{l}\text { - } \quad \text { more frequently in European ancestry patients } \\
\text { - } \quad \text { mostly in primary melanomas [93] }\end{array}$ \\
\hline TP53 & $6 / 67-8.9 \%$ & $\begin{array}{l}\text { - is correlated with response to immunotherapy with CTLA-4 } \\
\text { blockade [100] }\end{array}$ \\
\hline SPRED1 & $5 / 67-7.4 \%$ & $\begin{array}{l}\text { - deletion of the SPRED1 gene leads to developing resistance to } \\
\text { MAPK inhibition, so this mutation is essential in evaluating the } \\
\text { choice of treatment [101] }\end{array}$ \\
\hline ATRX & $4 / 67-5.9 \%$ & $\begin{array}{l}\text { - ATRX works as a chromatin remodeler, thus progression of a } \\
\text { melanoma lesion is associated with a reduced expression of ATRX } \\
\text { gene [102] }\end{array}$ \\
\hline HLA-A & $4 / 67-5.9 \%$ & [93] \\
\hline CHD8 & $3 / 67-4.4 \%$ & [93] \\
\hline
\end{tabular}

\section{Melanoma Stage Description}

Detection of a melanoma involving the vulva or vagina associates an essential step: the exclusion of any kind of metastatic dissemination in places such as mucosal membranes, skin, or the eyes [102]. Since staging approved for melanomas, in general, cannot be extended to female genital tract melanomas, there is a great need for dedicated staging. 
Clark classification that stages melanomas regarding their level of invasiveness and Breslow classification regarding the vertical depth of the lesion are dedicated for cutaneous melanomas [103-105].

A new and modified Clark classification, named Chung classification, is considered specific for micro-staging of mucosal melanomas in general (Table 3) [106].

Table 3. Clark and Chung classifications comparative aspects [104-106].

\begin{tabular}{|c|c|c|}
\hline Level of Invasion & $\begin{array}{c}\text { Clark Classification-Level of Invasion of Cutaneous } \\
\text { Melanoma }\end{array}$ & $\begin{array}{l}\text { Chung Classification-Level of Invasion } \\
\text { of Mucosal Melanoma }\end{array}$ \\
\hline I & Lesions involving only the epidermis (in situ melanoma) & Tumor confined to the epithelium \\
\hline II & $\begin{array}{l}\text { Invasion of the papillary dermis-does not reach the } \\
\text { papillary-reticular dermal interface }\end{array}$ & $\begin{array}{l}\text { Tumor penetrates the basement membrane } \\
\text { and invades at a depth of }<1 \mathrm{~mm}\end{array}$ \\
\hline III & $\begin{array}{l}\text { Invasion fills and expands the papillary dermis but does not } \\
\text { extend to reticular dermis }\end{array}$ & Tumor invades at a depth of $1-2 \mathrm{~mm}$ \\
\hline IV & $\begin{array}{l}\text { Invasion into the reticular dermis but not into the } \\
\text { subcutaneous tissue }\end{array}$ & $\begin{array}{l}\text { Tumor invades at a depth of }>2 \mathrm{~mm} \text {, but } \\
\text { without reaching the subcutaneous fat }\end{array}$ \\
\hline $\mathbf{V}$ & $\begin{array}{l}\text { Invasion through the reticular dermis into the } \\
\text { subcutaneous tissue }\end{array}$ & Tumor penetrates the subcutaneous fat \\
\hline
\end{tabular}

A 25-year study that both encompasses clinical and pathological features of vulvar melanoma revealed that American Joint Committee on Cancer (AJCC) staging system is the unique prognostic factor for vulvar melanoma (Table 4) [57]. The AJCC system was revised in 2017, associating new prognostic factors [72].

Table 4. American Joint Committee-prognostic stage group for melanoma 2017 [57,72].

\begin{tabular}{|c|c|c|c|}
\hline STAGE & T (Tumor) & N (Nodules) & M (Metastasis) \\
\hline 0 & Tis & No & M0 \\
\hline IA & T1a & No & M0 \\
\hline IB & $\mathrm{T} 1 \mathrm{~b}, \mathrm{~T} 2 \mathrm{a}$ & No & M0 \\
\hline IIA & $\mathrm{T} 2 \mathrm{~b}, \mathrm{~T} 3 \mathrm{a}$ & No & M0 \\
\hline IIB & $\mathrm{T} 3 \mathrm{~b}, \mathrm{~T} 4 \mathrm{a}$ & No & M0 \\
\hline IIC & $\mathrm{T} 4 \mathrm{~b}$ & No & M0 \\
\hline IIIA & $\mathrm{T} 1 \mathrm{a} / \mathrm{b}, \mathrm{T} 2 \mathrm{a}$ & $\mathrm{N} 1, \mathrm{~N} 2 \mathrm{a}$ & M0 \\
\hline \multirow[t]{3}{*}{ IIIB } & T0 & $\mathrm{N} 1 b, \mathrm{~N} 1 \mathrm{c}$ & M0 \\
\hline & $\mathrm{T} 1 \mathrm{a} / \mathrm{b}, \mathrm{T} 2 \mathrm{a}$ & $\mathrm{N} 1 \mathrm{~b} / \mathrm{c}, \mathrm{N} 2 \mathrm{~b}$ & M0 \\
\hline & $\mathrm{T} 2 \mathrm{~b}, \mathrm{~T} 3 \mathrm{a}$ & N1a-N2b & M0 \\
\hline \multirow[t]{4}{*}{ IIIC } & T0 & $\mathrm{N} 2 \mathrm{~b} / \mathrm{c}, \mathrm{N} 3 \mathrm{~b} / \mathrm{c}$ & M0 \\
\hline & T1a-T3a & N2c, N3 & M0 \\
\hline & $\mathrm{T} 3 \mathrm{~b}, \mathrm{~T} 4 \mathrm{a}$ & $\mathrm{N} \geq \mathrm{N} 1$ & M0 \\
\hline & $\mathrm{T} 4 \mathrm{~b}$ & N1a-N2c & M0 \\
\hline IIID & $\mathrm{T} 4 \mathrm{~b}$ & N3 & M0 \\
\hline IV & Any $\mathrm{T}$, Tis & Any N & M1 \\
\hline
\end{tabular}

\section{Therapeutic Approach}

Melanomas with vulvar and vaginal localization represent real challenges in terms of treatment, not only due to late diagnosis in locally advanced or metastatic stages, but also due to the absence of specific therapeutic guidelines due to the small number of cases. Thus, due to the impossibility of gathering a significant number of cases to establish dedicated guidelines, the guidelines for cutaneous melanoma are often used. 
The main treatment for both vulvar and vaginal melanoma is surgical excision of the tumor. Clinical experience in the last few decades has shown no significant differences in survival rates between radical excision and limited excisions with safety margins (Table 5), so limited resections are currently recommended [32,103]. Pelvic exenteration may be helpful, but only in carefully selected cases [107].

Table 5. Safety surgical margins in limited resection of vulvar and vaginal melanomas $[15,103,107]$.

\begin{tabular}{ccc}
\hline Tumor Width & Margins & Reference \\
\hline$<2 \mathrm{~mm}$ & $0.5 \mathrm{~cm}$ & \\
$2 \mathrm{~mm}$ & $1 \mathrm{~cm}$ & \\
$>2 \mathrm{~mm}$ & $2 \mathrm{~cm}$ & \\
\hline$<1 \mathrm{~mm}$ & $1 \mathrm{~cm}$ & {$[98]$} \\
$1-4 \mathrm{~mm}$ & $2 \mathrm{~cm}$ & \\
invasion of subcutaneous fat/fascia, any size & $>1 \mathrm{~cm}$ & {$[15]$} \\
\hline in situ & $0.5 \mathrm{~cm}$ & \\
$<2 \mathrm{~mm}$ & $1 \mathrm{~cm}$ & \\
\hline $2 \mathrm{~mm}$ & $2 \mathrm{~cm}$ & \\
\hline
\end{tabular}

Surgical excision may be completed in some cases by lymphadenectomy. Literature data do not provide specific information on the positive impact of lymphadenectomy in terms of survival, so it is preferred to perform the sentinel node technique in the absence of clinical involvement of regional lymph nodes, followed by lymphadenectomy in the case of a positive result [103]. In the case of clinical invasion of the regional lymph nodes, tumor extension in the adjacent structures, and/or ulceration, lymphadenectomy is recommended, not preceded by the sentinel node technique, which may or may not be followed by adjuvant treatment $[108,109]$. Lymphadenectomy, although a radical intervention, has no impact on long-term survival, only enabling better local control of the disease [107].

Regarding the utility of radiotherapy, chemotherapy, and immunotherapy, data presented in the literature are limited, but randomized controlled trials show minimal changes in survival [107]. Radiotherapy is generally used as neoadjuvant treatment, in case of impossibility of surgical resection, lymphatic invasion, regional extension, or as palliative treatment $[103,110]$. Doses of $45-55$ Gy are generally used in daily sessions of 1.8-2 Gy/session [103]. The use of radiotherapy in localized forms has been associated with a decrease in survival $[110,111]$.

Chemotherapy is mainly used as a neoadjuvant treatment or unique therapy, utilizing the same agents as those used in skin melanoma: dacarbazine and temozolomide, with dacarbazine being the first Food and Drug Administration-approved drug for melanoma treatment $[103,112]$. In addition, chemotherapy represents, together with surgery, the last therapeutic resource for the treatment of vulvar melanoma diagnosed in advanced stages [107].

Although on small groups of patients, there are studies showing the effectiveness of chemotherapy compared to the use of high-dose interferon for stage II vulvar melanoma [107]. Moreover, the use of temozolomide-cisplatin combination as adjuvant therapy in stages II-III showed statistically significant benefits over the use of interferon-alpha or surgery in terms of survival $(p<0.01)$ [109]. The carboplatin-paclitaxel-bevacizumab combination has been shown to be effective in decreasing tumor volume, thus allowing surgical resection without the need for further grafting [113]. Chemotherapy is used mainly in regionally advanced forms or with distant metastases, but the benefits are minimal, the use of chemotherapy is generally associated with a decrease in overall survival and recurrencefree survival [110,113]. Up until 2011, only four drugs had been approved for the treatment of melanoma; currently, their number has reached 30, and this increase is based mainly on newly emerged molecules from the class of immunotherapeutics or biological drugs [112].

The class of immunotherapeutics includes molecules that interfere with the immune cascade of carcinogenesis, such as interferon $\alpha-2 b$ (IFN $\alpha-2 b)$, peginterferon $\alpha-2 b$ (PegIFN 
$\alpha-2 b$ ), interleukin 2 (IL-2), inhibitor of death protein 1 (PD-L1 blockade)-nivolumab, regulatory $\mathrm{T}$ lymphocyte inhibitors, monoclonal antibodies against cytotoxic $\mathrm{T}$ cell antigen 4 (CTLA-4)-ipilimumab [112]. These are especially used in advanced stages (stage III-IV) of cutaneous melanoma, but for vulvar melanoma, there are not enough clinical data to demonstrate efficacy in terms of overall survival or disease-free survival. However, their use doubled in the period 2012-2015 compared to the corresponding previous period $(p<0.01)$, most frequently for regionally advanced forms and those with distant metastases [110]. IFN $\alpha-2 b$ appeared to lead to an increase in disease-free survival in a randomized clinical trial, while no effects on survival after the use of IL-2 alone or in combination with peptide vaccines were observed [107]. Albert et al. observed in a study on 1917 patients with vulvar melanoma (3/4 with localized disease) that the combination of immunotherapy with local surgery was associated with an increase in overall survival, although statistically insignificant [110]. On the other hand, the use of immunotherapy in combination with chemotherapy and biological therapy was associated with a decrease in overall survival and recurrence-free survival in a study on 48 patients with vulvar and vaginal melanomas [113]. The same data were supported by Tcheung et al. who did not find significant differences in overall survival in patients treated with immunotherapy and chemotherapy [114].

Although targeted therapy has evolved in the last years and significantly improved the prognosis of patients with cutaneous melanoma, its use in vulvar and vaginal melanomas is still limited by the different mutagenic profiles involving fewer BRAF mutations and more c-KIT, NF1 and SF3B1 mutations [91,112]. Thus, monoclonal antibodies such as imatinib, sunitinib, dasatinib, nilotinib (for c-kit mutations) could have been a promising option due to a large number of c-kit mutations, but the results are not as good as in the case of cutaneous melanoma. Imatinib has been shown to reduce tumor size and PET uptake, as well as the disappearance of metastases in a patient with recurrent vulvar melanoma and c-kit mutation in exon 13 [115]. There are phase II studies with promising results for the use of imatinib and dasatinib in patients with mucosal melanomas with c-kit mutations $[107,116]$. Cocorocchio et al. also mention a positive response to avapritinib therapy in a patient with advanced vulvar melanoma with a c-kit mutation in exon 17, who had a previous negative response to the ipilimumab-nivolumab combination [117].

The prognosis is generally poor, characterized by frequent recurrences (up to $70 \%$ ), with a low overall survival (average survival between 15-78 months), and with a recurrence disease-free interval of up to 64 months [113,114,118-121] (Table 6). The main prognostic factors are tumor size, lymphatic invasion, Breslow depth, and the presence of ulcerated lesions [114,122].

Vaginal melanoma is characterized by higher recurrence rates and lower average survival, requiring wider excisions with complete lymphadenectomy and even pelvic exenteration $[113,121,123,124]$. Along with the surgical excision, adjuvant chemotherapy (dacarbazine) or the combination of targeted therapy (ipilimumab)-radiotherapy have been mentioned in the literature in isolated case presentations or case series, with favorable results $[113,121]$. In the case of the combination of ipilimumab-radiotherapy, it was found that the administration of radiotherapy in doses of $3000 \mathrm{cGy}$ in 5 fractions was accompanied by the absence of recurrences compared to radiotherapy in doses of 6020 cGy in 28 fractions (for isolated cases, no statistical significance was demonstrated in randomized clinical trials) [113]. 
Table 6. Survival rates according to type of treatment [110,114-116,118].

\begin{tabular}{|c|c|c|c|c|c|}
\hline Number of Patients & Mean Depth Invasion & Management & Median Survival (Months) & Reccurence & Reference \\
\hline 13 & Not provided & Not provided & 15 & Not provided & [119] \\
\hline 7 & $8 \mathrm{~mm}$ & Wide local excision & 31 & $71 \%$ & [118] \\
\hline 14 & $3.23 \mathrm{~mm}$ & $\begin{array}{l}\text { 13\% Radical surgery and } \\
\text { lymphadenectomy } \\
\text { 27\% Wide local excision } \\
\text { and lymph node evaluation } \\
\text { 53\% Wide local excision }\end{array}$ & Not provided & $42 \%$ & [122] \\
\hline 9 & $4 \mathrm{~mm}$ & $\begin{array}{l}\text { Radical surgery and } \\
\text { lymphadenectomy }\end{array}$ & 78 & $\begin{array}{c}\text { 32-43\% (in } \\
\text { situ) }\end{array}$ & [120] \\
\hline 85 & $3.2 \mathrm{~mm}$ & $\begin{array}{c}\text { 12.9\% Chemotherapy } \\
24.7 \% \text { Immunotherapy } \\
\text { (IL-2, IFN, vaccine trials) } \\
2.35 \% \text { Chemotherapy and } \\
\text { Immunotherapy } \\
\text { 15.29\% Radiotherapy } \\
78.8 \% \text { Surgery }\end{array}$ & 62.4 & Not provided & [114] \\
\hline 48 & $>3 \mathrm{~mm}$ & $\begin{array}{l}\text { 29.58\% Wide local excision } \\
\text { and lymphadenectomy } \\
21.42 \% \text { Radical surgery ( } 8 \% \\
\text { pelvic exenteration) }\end{array}$ & 39.6 & Not provided & [113] \\
\hline 1917 & Not provided & $\begin{array}{c}\text { 95.044\% Surgery } \\
\text { 10.38\% Radiation } \\
\text { 9.99\% Immunotherapy } \\
5.32 \% \text { Chemotherapy }\end{array}$ & Not provided & Not provided & {$[110]$} \\
\hline
\end{tabular}

\section{Conclusions}

Vulvar and vaginal melanomas are rare neoplasms, with aggressive evolution, most often diagnosed in advanced stages. Gynecological melanomas currently represent a discouraging diagnosis due to the absence of specific therapeutic guidelines and management measures with satisfactory results. Despite the significant development of targeted therapy that has brought major benefits in the prognosis of cutaneous melanoma, vulvar and vaginal melanoma have a low response to these therapies due to the presence of different mutagenic profiles. Thus, despite the use in various clinical trials of many types of targeted therapies, or combinations of chemotherapy and immunotherapy, surgical excision within safe limits remains the therapeutic approach with the best survival rate. The molecular mechanisms of the vulvar and vaginal melanomas are not yet fully understood, these types of melanomas being considered an independent subcategory of melanoma. As new mechanisms are discovered, new targeted therapies may appear to improve the prognosis and subsequently, the survival rates.

Author Contributions: Conceptualization, E.-C.D., C.E.C., B.S.G. and S.M.C.; methodology, E.-C.D.; software, E.-C.D., C.V., S.M.C. and D.C.; validation, E.-C.D., C.V., S.M.C. and D.C.; formal analysis, E.-C.D., C.V., S.M.C., N.S. and D.C.; investigation E.-C.D., C.E.C., S.M.C. and V.N.V.; resources, E.-C.D., C.V., S.M.C., I.P. and D.C.; data curation, E.-C.D., C.V., N.S. and S.M.C.; writing-original draft preparation, E.-C.D., C.V., I.P. and S.M.C.; writing-review and editing, E.-C.D., B.S.G., C.E.C., S.M.C. and V.N.V.; visualization, E.-C.D., C.E.C. and S.M.C.; supervision, B.S.G.; S.M.C.; project administration, E.-C.D., C.V. and S.M.C. All authors have read and agreed to the published version of the manuscript.

Funding: This work was supported by a grant of the Romanian Ministry of Research and Innovation, PCCDI-UEFISCDI, projects number PN-III-P1-1.2-PCCDI-2017-0833/68/2018, and PN-III-P1-1.2PCCDI-2017-0820/67/2018 within PNCDI III.

Institutional Review Board Statement: Not applicable.

Informed Consent Statement: Not applicable.

Conflicts of Interest: The authors declare no conflict of interest. 


\section{References}

1. Liu, Y.; Sheikh, M.S. Melanoma: Molecular Pathogenesis and Therapeutic Management. Mol. Cell. Pharmacol. 2014, 6, 228. [PubMed]

2. Mort, R.L.; Jackson, I.J.; Patton, E.E. The Melanocyte Lineage in Development and Disease. Development 2015, 142, 620-632. [CrossRef]

3. Ali, S.A.; Naaz, I. Current Challenges in Understanding the Story of Skin Pigmentation—Bridging the Morpho-Anatomical and Functional Aspects of Mammalian Melanocytes. In Muscle Cell and Tissue; Sakuma, K., Ed.; InTech: London, UK, 2015.

4. Skin Cancer Statistics. Available online: https://www.wcrf.org/dietandcancer/cancer-trends/skin-cancer-statistics (accessed on 25 April 2021).

5. Melanoma Skin Cancer Statistics. Available online: https://www.cancer.org/cancer/melanoma-skin-cancer/about/key-statistics. html (accessed on 25 April 2021).

6. Weir, H.K.; Marrett, L.D.; Cokkinides, V.; Barnholtz-Sloan, J.; Patel, P.; Tai, E.; Jemal, A.; Li, J.; Kim, J.; Ekwueme, D.U. Melanoma in Adolescents and Young Adults (Ages 15-39 Years): United States, 1999-2006. J. Am. Acad. Dermatol. 2011, 65, S38-S49. [CrossRef]

7. Olsen, C.M.; Thompson, J.F.; Pandeya, N.; Whiteman, D.C. Evaluation of Sex-Specific Incidence of Melanoma. JAMA Dermatol. 2020, 156, 553-560. [CrossRef]

8. Paulson, K.G.; Gupta, D.; Kim, T.S.; Veatch, J.R.; Byrd, D.R.; Bhatia, S.; Wojcik, K.; Chapuis, A.G.; Thompson, J.A.; Madeleine, M.M.; et al. Age-Specific Incidence of Melanoma in the United States. JAMA Dermatol. 2020, 156, 57-64. [CrossRef] [PubMed]

9. Davis, L.E.; Shalin, S.C.; Tackett, A.J. Current State of Melanoma Diagnosis and Treatment. Cancer Biol. Ther. 2019, 20, 1366-1379. [CrossRef] [PubMed]

10. Matthews, N.H.; Li, W.-Q.; Qureshi, A.A.; Weinstock, M.A.; Cho, E. Cutaneous Melanoma: Etiology and Therapy. Codon Publ. 2017. [CrossRef]

11. Corona, R.; Mele, A.; Amini, M.; De Rosa, G.; Coppola, G.; Piccardi, P.; Fucci, M.; Pasquini, P.; Faraggiana, T. Interobserver Variability on the Histopathologic Diagnosis of Cutaneous Melanoma and Other Pigmented Skin Lesions. J. Clin. Oncol. 1996, 14, 1218-1223. [CrossRef]

12. Troxel, D.B. Pitfalls in the Diagnosis of Malignant Melanoma: Findings of a Risk Management Panel Study. Am. J. Surg. Pathol. 2003, 27, 1278-1283. [CrossRef]

13. Trimble, E.L. Melanomas of the Vulva and Vagina. Oncol. Williston Park 1996, 10, 1017-1023.

14. Qurrat ul Ain, Q.; Rao, B. A Rare Case Report: Malignant Vulvar Melanoma. Indian J. Gynecol. Oncol. 2020, 18. [CrossRef]

15. Boer, F.L.; Ten Eikelder, M.L.G.; Kapiteijn, E.H.; Creutzberg, C.L.; Galaal, K.; van Poelgeest, M.I.E. Vulvar Malignant Melanoma: Pathogenesis, Clinical Behaviour and Management: Review of the Literature. Cancer Treat. Rev. 2019, 73, 91-103. [CrossRef] [PubMed]

16. Ragnarsson-Olding, B.K. Primary Malignant Melanoma of the Vulva-An Aggressive Tumor for Modeling the Genesis of Non-UV Light-Associated Melanomas. Acta Oncol. 2004, 43, 421-435. [CrossRef] [PubMed]

17. Heinzelmann-Schwarz, V.A.; Nixdorf, S.; Valadan, M.; Diczbalis, M.; Olivier, J.; Otton, G.; Fedier, A.; Hacker, N.F.; Scurry, J.P. A Clinicopathological Review of 33 Patients with Vulvar Melanoma Identifies C-KIT as a Prognostic Marker. Int. J. Mol. Med. 2014, 33, 784-794. [CrossRef]

18. Wohlmuth, C.; Wohlmuth-Wieser, I. Vulvar Malignancies: An Interdisciplinary Perspective. J. Dtsch. Dermatol. Ges. 2019, 17, 1257-1276. [CrossRef] [PubMed]

19. Jamaer, E.; Liang, Z.; Stagg, B. Primary Malignant Melanoma of the Vagina. BMJ Case Rep. 2020, 13, e232200. [CrossRef]

20. Kalampokas, E.; Kalampokas, T.; Damaskos, C. Primary Vaginal Melanoma, A Rare and Aggressive Entity. A Case Report and Review of the Literature. In Vivo 2017, 31, 133-139. [CrossRef]

21. Wohlmuth, C.; Wohlmuth-Wieser, I.; May, T.; Vicus, D.; Gien, L.T.; Laframboise, S. Malignant Melanoma of the Vulva and Vagina: A US Population-Based Study of 1863 Patients. Am. J. Clin. Dermatol. 2020, 217, 285-295. [CrossRef]

22. Hu, D.-N.; Yu, G.-P.; McCormick, S.A. Population-Based Incidence of Vulvar and Vaginal Melanoma in Various Races and Ethnic Groups with Comparisons to Other Site-Specific Melanomas. Melanoma Res. 2010, 20, 153-158. [CrossRef]

23. Riker, A.I.; Zea, N.; Trinh, T. The Epidemiology, Prevention, and Detection of Melanoma. Ochsner J. $2010,10,56-65$.

24. Scheistrøen, M.; Tropé, C.; Kaern, J.; Abeler, V.M.; Pettersen, E.O.; Kristensen, G.B. Malignant Melanoma of the Vulva FIGO Stage I: Evaluation of Prognostic Factors in 43 Patients with Emphasis on DNA Ploidy and Surgical Treatment. Gynecol. Oncol. 1996, 61, 253-258. [CrossRef] [PubMed]

25. Harting, M.S.; Kim, K.B. Biochemotherapy in Patients with Advanced Vulvovaginal Mucosal Melanoma. Melanoma Res. 2004, 14, 517-520. [CrossRef] [PubMed]

26. Baiocchi, G.; Duprat, J.P.; Neves, R.I.; Fukazawa, E.M.; Landman, G.; Guimarães, G.C.; Valadares, L.J. Vulvar Melanoma: Report on Eleven Cases and Review of the Literature. Sao Paulo Med. J. 2010, 128, 38-41. [CrossRef]

27. You, J.S.; Jones, P.A. Cancer Genetics and Epigenetics: Two Sides of the Same Coin? Cancer Cell 2012, 22, 9-20. [CrossRef]

28. Rastrelli, M.; Tropea, S.; Rossi, C.R.; Alaibac, M. Melanoma: Epidemiology, Risk Factors, Pathogenesis, Diagnosis and Classification. In Vivo 2014, 28, 1005-1011. 
29. Gandini, S.; Sera, F.; Cattaruzza, M.S.; Pasquini, P.; Picconi, O.; Boyle, P.; Melchi, C.F. Meta-Analysis of Risk Factors for Cutaneous Melanoma: II. Sun Exposure. Eur. J. Cancer 2005, 41, 45-60. [CrossRef] [PubMed]

30. Bevona, C.; Goggins, W.; Quinn, T.; Fullerton, J.; Tsao, H. Cutaneous Melanomas Associated with Nevi. Arch. Dermatol. 2003, 139, 1620-1624. [CrossRef]

31. Stern, R.S.; PUVA Follow up Study. The Risk of Melanoma in Association with Long-Term Exposure to PUVA. J. Am. Acad. Dermatol. 2001, 44, 755-761. [CrossRef]

32. Mihajlovic, M.; Vlajkovic, S.; Jovanovic, P.; Stefanovic, V. Primary Mucosal Melanomas: A Comprehensive Review. Int. J. Clin. Exp. Pathol. 2012, 5, 739-753.

33. Rapi, V.; Dogan, A.; Schultheis, B.; Hartmann, F.; Rezniczek, G.A.; Tempfer, C.B. Melanoma of the Vagina: Case Report and Systematic Review of the Literature. Anticancer Res. 2017, 37, 6911-6920.

34. Stang, A.; Streller, B.; Eisinger, B.; Jöckel, K.H. Population-Based Incidence Rates of Malignant Melanoma of the Vulva in Germany. Gynecol. Oncol. 2005, 96, 216-221. [CrossRef]

35. Tasseron, E.W.; van der Esch, E.P.; Hart, A.A.; Brutel de la Rivière, G.; Aartsen, E.J. A Clinicopathological Study of 30 Melanomas of the Vulva. Gynecol. Oncol. 1992, 46, 170-175. [CrossRef]

36. Wechter, M.E.; Gruber, S.B.; Haefner, H.K.; Lowe, L.; Schwartz, J.L.; Reynolds, K.R.; Johnston, C.M.; Johnson, T.M. Vulvar Melanoma: A Report of 20 Cases and Review of the Literature. J. Am. Acad. Dermatol. 2004, 50, 554-562. [CrossRef] [PubMed]

37. Mert, I.; Semaan, A.; Winer, I.; Morris, R.T.; Ali-Fehmi, R. Vulvar/Vaginal Melanoma: An Updated Surveillance Epidemiology and End Results Database Review, Comparison with Cutaneous Melanoma and Significance of Racial Disparities. Int. J. Gynecol. Cancer 2013, 23, 1118-1126. [CrossRef] [PubMed]

38. Hassanein, A.M.; Mrstik, M.E.; Hardt, N.S.; Morgan, L.A.; Wilkinson, E.J. Malignant Melanoma Associated with Lichen Sclerosus in the Vulva of a 10-Year-Old. Pediatr. Dermatol. 2004, 21, 473-476. [CrossRef]

39. Hieta, N.; Kurki, S.; Rintala, M.; Söderlund, J.; Hietanen, S.; Orte, K. Association of Vulvar Melanoma with Lichen Sclerosus. Acta Derm. Venereol. 2019, 99, 339-340. [CrossRef]

40. Zekan, J.; Sirotkovic-Skerlev, M.; Skerlev, M. Oncogenic Aspects of HPV Infections of the Female Genital Tract. In DNA Replication-Current Advances; Seligmann, H., Ed.; InTech: London, UK, 2011.

41. Münger, K.; Baldwin, A.; Edwards, K.M.; Hayakawa, H.; Nguyen, C.L.; Owens, M.; Grace, M.; Huh, K. Mechanisms of Human Papillomavirus-Induced Oncogenesis. J. Virol. 2004, 78, 11451-11460. [CrossRef]

42. Crum, C.P.; McLachlin, C.M.; Tate, J.E.; Mutter, G.L. Pathobiology of Vulvar Squamous Neoplasia. Curr. Opin. Obstet. Gynecol. 1997, 9, 63-69. [CrossRef] [PubMed]

43. Swetter, S.M.; Tsao, H.; Bichakjian, C.K.; Curiel-Lewandrowski, C.; Elder, D.E.; Gershenwald, J.E.; Guild, V.; Grant-Kels, J.M.; Halpern, A.C.; Johnson, T.M.; et al. Guidelines of Care for the Management of Primary Cutaneous Melanoma. J. Am. Acad. Dermatol. 2019, 80, 208-250. [CrossRef] [PubMed]

44. Edwards, L. Pigmented Vulvar Lesions: Pigmented Vulvar Lesions. Dermatol. Ther. 2010, 23, 449-457. [CrossRef]

45. Resende, F.S.; Conforti, C.; Giuffrida, R.; de Barros, M.H.; Zalaudek, I. Raised Vulvar Lesions: Be Aware! Dermatol. Pract. Concept. 2018, 8, 158-161. [CrossRef]

46. Sand, F.L.; Thomsen, S.F. Clinician's Update on the Benign, Premalignant, and Malignant Skin Tumours of the Vulva: The Dermatologist's View. Int. Sch. Res. Not. 2017, 2017, 2414569. [CrossRef]

47. De Simone, P.; Silipo, V.; Buccini, P.; Mariani, G.; Marenda, S.; Eibenschutz, L.; Ferrari, A.; Catricalà, C. Vulvar Melanoma: A Report of 10 Cases and Review of the Literature. Melanoma Res. 2008, 18, 127-133. [CrossRef] [PubMed]

48. Genton, C.Y.; Kunz, J.; Schreiner, W.E. Primary Malignant Melanoma of the Vagina and Cervix Uteri: Report of a Case with Utrastructural Study. Virchows Arch. A Path. Anat. Histol. 1981, 393, 245-250.

49. Hewitt, P. Sequel to a Case of Recurrent Melanosis of Both Groins and Back: The Disease Reappearing in the Brain, Heart, Pancreas, Liver and Other Organs. Lancet 1861, 77, 263.

50. Panizzon, R.G. Vulvar Melanoma. Semin. Dermatol. 1996, 15, 67-70. [CrossRef]

51. Pirlamarla, A.K.; Tang, J.; Amin, B.; Kabarriti, R. Vulvar Melanoma with Isolated Metastasis to the Extraocular Muscles: Case Report and Brief Literature Review. Anticancer Res. 2018, 38, 3763-3766. [CrossRef]

52. Campaner, A.B.; Fernandes, G.L.; de Cardoso, F.A.; Veasey, J.V. Vulvar Melanoma: Relevant Aspects in Therapeutic Management. An. Bras. Dermatol. 2017, 92, 398-400. [CrossRef]

53. Baderca, F.; Cojocaru, S.; Lazăr, E.; Lăzureanu, C.; Lighezan, R.; Alexa, A.; Raica, M.; Nicola, T. Amelanotic Vulvar Melanoma: Case Report and Review of the Literature. Rom. J. Morphol. Embryol. 2008, 49, 219-228.

54. Filippetti, R.; Pitocco, R. Amelanotic Vulvar Melanoma: A Case Report. Am. J. Dermatopathol. 2015, 37, e75-e77. [CrossRef]

55. Mukeya, G.K.; Kakoka, I.M.; Mwansa, J.C.; Kalau, W.A. Mélanome malin vulvaire: À propos d'un cas observé à l’Hôpital du Cinquantenaire de Lubumbashi. Pan Afr. Med. J. 2020, 36, 124. [CrossRef]

56. Sinasac, S.E.; Petrella, T.M.; Rouzbahman, M.; Sade, S.; Ghazarian, D.; Vicus, D. Melanoma of the Vulva and Vagina: Surgical Management and Outcomes Based on a Clinicopathologic Reviewof 68 Cases. J. Obstet. Gynaecol. Can. 2019, 41, 762-771. [CrossRef]

57. Verschraegen, C.F.; Benjapibal, M.; Supakarapongkul, W.; Levy, L.B.; Ross, M.; Atkinson, E.N.; Bodurka-Bevers, D.; Kavanagh, J.J.; Kudelka, A.P.; Legha, S.S. Vulvar Melanoma at the M. D. Anderson Cancer Center: 25 Years Later. Int. J. Gynecol. Cancer 2001, 11, 359-364. [CrossRef] [PubMed] 
58. Vaccari, S.; Barisani, A.; Salvini, C.; Pirola, S.; Preti, E.P.; Pennacchioli, E.; Iacobone, A.D.; Patrizi, A.; Tosti, G. Thin Vulvar Melanoma: A Challenging Diagnosis. Dermoscopic Features of a Case Series. Clin. Exp. Dermatol. 2020, 45, 187-193. [CrossRef]

59. Pandey, G.; Dave, P.; Patel, S.; Patel, B.; Arora, R.; Parekh, C.; Begum, D. Female Genital Tract Melanoma: Analysis from a Regional Cancer Institute. J. Turk. Soc. Obstet. Gynecol. 2020, 17, 46-51. [CrossRef] [PubMed]

60. Joste, M.; Dion, L.; Brousse, S.; Nyangoh Timoh, K.; Rousseau, C.; Reilhac, A.; Laviolle, B.; Lesimple, T.; Lavoue, V.; Leveque, J. Vulvar and Vaginal Melanomas: A Retrospective Study Spanning 19 Years from a Tertiary Center. J. Gynecol. Obstet. Hum. Reprod. 2021, 50, 102091. [CrossRef] [PubMed]

61. Martin-Gorgojo, A.; Comunion-Artieda, A.; Pizarro-Redondo, A.; Bru-Gorraiz, F.-J. A Minute 'Ugly-Duckling' Pigmented Lesion on the Arm of a 60-Year-Old Caucasian Female. In Clinical Cases in Melanoma; Springer International Publishing: Cham, Switzerland, 2020; pp. 29-31.

62. Rogers, T.; Pulitzer, M.; Marino, M.L.; Marghoob, A.A.; Zivanovic, O.; Marchetti, M.A. Early Diagnosis of Genital Mucosal Melanoma: How Good Are Our Dermoscopic Criteria? Dermatol. Pract. Concept. 2016, 6, 43-46. [CrossRef]

63. Oguri, H.; Izumiya, C.; Maeda, N.; Fukaya, T.; Moriki, T. A Primary Amelanotic Melanoma of the Vagina, Diagnosed by Immunohistochemical Staining with HMB-45, Which Recurred as a Pigmented Melanoma. J. Clin. Pathol. 2004, 57, 986-988. [CrossRef]

64. Gautam, D.; Ahmed, M. Melanoma Detection and Classification Using SVM Based Decision Support System. In Proceedings of the 2015 Annual IEEE India Conference (INDICON), New Delhi, India, 17-20 December 2015; pp. 1-6.

65. Goldsmith, S.M.; Solomon, A.R. A Series of Melanomas Smaller than $4 \mathrm{Mm}$ and Implications for the ABCDE Rule. J. Eur. Acad. Dermatol. Venereol. 2007, 21, 929-934. [CrossRef]

66. Blum, A.; Simionescu, O.; Argenziano, G.; Braun, R.; Cabo, H.; Eichhorn, A.; Kirchesch, H.; Malvehy, J.; Marghoob, A.A.; Puig, S.; et al. Dermoscopy of Pigmented Lesions of the Mucosa and the Mucocutaneous Junction: Results of a Multicenter Study by the International Dermoscopy Society (IDS): Results of a Multicenter Study by the International Dermoscopy Society (IDS). Arch. Dermatol. 2011, 147, 1181-1187. [CrossRef]

67. Lee, Y.-T. Diagnosis, Treatment and Prognosis of Early Melanoma: The Importance of Depth of Microinvasion. Ann. Surg. 1980, 191, 87-97. [CrossRef]

68. Pflugfelder, A.; Weide, B.; Eigentler, T.K.; Forschner, A.; Leiter, U.; Held, L.; Meier, F.; Garbe, C. Incisional Biopsy and Melanoma Prognosis: Facts and Controversies. Clin. Dermatol. 2010, 28, 316-318. [CrossRef] [PubMed]

69. Tadiparthi, S.; Panchani, S.; Iqbal, A. Biopsy for Malignant Melanoma-Are We Following the Guidelines? Ann. R. Coll. Surg. Engl. 2008, 90, 322-325. [CrossRef] [PubMed]

70. Dickson, P.V.; Gershenwald, J.E. Staging and Prognosis of Cutaneous Melanoma. Surg. Oncol. Clin. N. Am. 2011, 20, 1-17. [CrossRef]

71. Keung, E.Z.; Gershenwald, J.E. The Eighth Edition American Joint Committee on Cancer (AJCC) Melanoma Staging System: Implications for Melanoma Treatment and Care. Expert Rev. Anticancer Ther. 2018, 18, 775-784. [CrossRef]

72. Gershenwald, J.E.; Scolyer, R.A.; Hess, K.R.; Sondak, V.K.; Long, G.V.; Ross, M.I.; Lazar, A.J.; Faries, M.B.; Kirkwood, J.M.; McArthur, G.A.; et al. Melanoma Staging: Evidence-Based Changes in the American Joint Committee on Cancer Eighth Edition Cancer Staging Manual. CA Cancer J. Clin. 2017, 67, 472-492. [CrossRef]

73. Hou, J.Y.; Baptiste, C.; Hombalegowda, R.B.; Tergas, A.I.; Feldman, R.; Jones, N.L.; Chatterjee-Paer, S.; Bus-Kwolfski, A.; Wright, J.D.; Burke, W.M. Vulvar and Vaginal Melanoma: A Unique Subclass of Mucosal Melanoma Based on a Comprehensive Molecular Analysis of 51 Cases Compared with 2253 Cases of Nongynecologic Melanoma: Molecular Study of Vulvovaginal Melanoma. Cancer 2017, 123, 1333-1344. [CrossRef] [PubMed]

74. Coit, D.G.; Andtbacka, R.; Anker, C.J.; Bichakjian, C.K.; Carson, W.E., III; Daud, A.; DiMaio, D.; Fleming, M.D.; Guild, V.; Halpern, A.C.; et al. Melanoma, Version 2.2013: Featured Updates to the NCCN Guidelines. J. Natl. Compr. Canc. Netw. 2013, 11, 395-407. [CrossRef]

75. Smoller, B.R. Histologic Criteria for Diagnosing Primary Cutaneous Malignant Melanoma. Mod. Pathol. 2006, 19, S34-S40. [CrossRef] [PubMed]

76. Connolly, K.L.; Nehal, K.S.; Busam, K.J. Lentigo Maligna and Lentigo Maligna Melanoma: Contemporary Issues in Diagnosis and Management. Melanoma Manag. 2015, 2, 171-178. [CrossRef]

77. Saida, T.; Koga, H.; Goto, Y.; Uhara, H. Characteristic Distribution of Melanin Columns in the Cornified Layer of Acquired Acral Nevus: An Important Clue for Histopathologic Differentiation from Early Acral Melanoma. Am. J. Dermatopathol. 2011, 33, 468-473. [CrossRef] [PubMed]

78. James, W.; Elston, D.; Treat, J.; Rosenbach, M.; Micheletti, R. Melanocytic Nevi and Neoplasms. In Andrews' Diseases of the Skin; Elsevier: Amsterdam, The Netherlands, 2019.

79. DeMatos, P.; Tyler, D.; Seigler, H.F. Mucosal Melanoma of the Female Genitalia: A Clinicopathologic Study of Forty-Three Cases at Duke University Medical Center. Surgery 1998, 124, 38-48. [CrossRef]

80. Petković, M.; Jurakić Tončić, R. Nested Melanoma, a New Morphological Variant of Superficial Spreading Melanoma with Characteristic Dermoscopic Features. Acta Dermatovenerol. Croat. 2017, 25, 80-81.

81. Urso, C.; Rongioletti, F.; Innocenzi, D.; Batolo, D.; Chimenti, S.; Fanti, P.L.; Filotico, R.; Gianotti, R.; Lentini, M.; Tomasini, C.; et al. Histological Features Used in the Diagnosis of Melanoma Are Frequently Found in Benign Melanocytic Naevi. J. Clin. Pathol. 2005, 58, 409-412. [CrossRef] 
82. Banerjee, S.S.; Harris, M. Morphological and Immunophenotypic Variations in Malignant Melanoma: Variations in Malignant Melanoma. Histopathology 2000, 36, 387-402. [CrossRef]

83. Nadji, M.; Ganjei, P.; Penneys, N.S.; Morales, A.R. Immunohistochemistry of Vulvar Neoplasms: A Brief Review. Int. J. Gynecol. Pathol. 1984, 3, 41-50. [CrossRef]

84. Xu, X.; Chu, A.Y.; Pasha, T.L.; Elder, D.E.; Zhang, P.J. Immunoprofile of MITF, Tyrosinase, Melan-A, and MAGE-1 in HMB45Negative Melanomas. Am. J. Surg. Pathol. 2002, 26, 82-87. [CrossRef] [PubMed]

85. Cochran, A.J.; Wen, D.R. S-100 Protein as a Marker for Melanocytic and Other Tumours. Pathology 1985, 17, 340-345. [CrossRef] [PubMed]

86. Wick, M.R.; Swanson, P.E.; Rocamora, A. Recognition of Malignant Melanoma by Monoclonal Antibody HMB-45. An Immunohistochemical Study of 200 Paraffin-Embedded Cutaneous Tumors. J. Cutan. Pathol. 1988, 15, 201-207. [CrossRef]

87. Orchard, G.E. Comparison of Immunohistochemical Labelling of Melanocyte Differentiation Antibodies Melan-A, Tyrosinase and HMB 45 with NKIC3 and S100 Protein in the Evaluation of Benign Naevi and Malignant Melanoma. Histochem. J. 2000, 32, 475-481. [CrossRef]

88. Willis, B.C.; Johnson, G.; Wang, J.; Cohen, C. SOX10: A Useful Marker for Identifying Metastatic Melanoma in Sentinel Lymph Nodes. Appl. Immunohistochem. Mol. Morphol. 2015, 23, 109-112. [CrossRef]

89. D'Angelo, S.P.; Larkin, J.; Sosman, J.A.; Lebbé, C.; Brady, B.; Neyns, B.; Schmidt, H.; Hassel, J.C.; Hodi, F.S.; Lorigan, P.; et al. Efficacy and Safety of Nivolumab Alone or in Combination with Ipilimumab in Patients with Mucosal Melanoma: A Pooled Analysis. J. Clin. Oncol. 2017, 35, 226-235. [CrossRef] [PubMed]

90. Yan, J.; Wu, X.; Yu, J.; Yu, H.; Xu, T.; Brown, K.M.; Bai, X.; Dai, J.; Ma, M.; Tang, H.; et al. Analysis of NRAS Gain in 657 Patients with Melanoma and Evaluation of Its Sensitivity to a MEK Inhibitor. Eur. J. Cancer 2018, 89, 90-101. [CrossRef]

91. Hintzsche, J.D.; Gorden, N.T.; Amato, C.M.; Kim, J.; Wuensch, K.E.; Robinson, S.E.; Applegate, A.J.; Couts, K.L.; Medina, T.M.; Wells, K.R.; et al. Whole-Exome Sequencing Identifies Recurrent SF3B1 R625 Mutation and Comutation of NF1 and KIT in Mucosal Melanoma. Melanoma Res. 2017, 27, 189-199. [CrossRef]

92. Lyu, J.; Song, Z.; Chen, J.; Shepard, M.J.; Song, H.; Ren, G.; Li, Z.; Guo, W.; Zhuang, Z.; Shi, Y. Whole-Exome Sequencing of Oral Mucosal Melanoma Reveals Mutational Profile and Therapeutic Targets: WES of OMM Reveals Genomic Alterations. J. Pathol. 2018, 244, 358-366. [CrossRef] [PubMed]

93. Newell, F.; Kong, Y.; Wilmott, J.S.; Johansson, P.A.; Ferguson, P.M.; Cui, C.; Li, Z.; Kazakoff, S.H.; Burke, H.; Dodds, T.J.; et al. Whole-Genome Landscape of Mucosal Melanoma Reveals Diverse Drivers and Therapeutic Targets. Nat. Commun. 2019, 10, 3163. [CrossRef] [PubMed]

94. Rouzbahman, M.; Kamel-Reid, S.; Al Habeeb, A.; Butler, M.; Dodge, J.; Laframboise, S.; Murphy, J.; Rasty, G.; Ghazarian, D. Malignant Melanoma of Vulva and Vagina: A Histomorphological Review and Mutation Analysis-A Single-Center Study. J. Low. Genit. Tract Dis. 2015, 19, 350-353. [CrossRef]

95. Cai, Y.-J.; Ke, L.-F.; Zhang, W.-W.; Lu, J.-P.; Chen, Y.-P. Recurrent KRAS, KIT and SF3B1 Mutations in Melanoma of the Female Genital Tract. BMC Cancer 2021, 21, 677. [CrossRef]

96. Nassar, K.W.; Tan, A.C. The Mutational Landscape of Mucosal Melanoma. Semin. Cancer Biol. 2020, 61, 139-148. [CrossRef]

97. Kiuru, M.; Busam, K.J. The NF1 Gene in Tumor Syndromes and Melanoma. Lab. Investig. 2017, 97, 146-157. [CrossRef]

98. Guillot, B.; Dalac, S.; Delaunay, M.; Baccard, M.; Chevrant-Breton, J.; Dereure, O.; Machet, L.; Sassolas, B.; Zeller, J.; Bernard, P.; et al. Cutaneous Malignant Melanoma and Neurofibromatosis Type 1. Melanoma Res. 2004, 14, 159-163. [CrossRef] [PubMed]

99. Omholt, K.; Grafström, E.; Kanter-Lewensohn, L.; Hansson, J.; Ragnarsson-Olding, B.K. KIT Pathway Alterations in Mucosal Melanomas of the Vulva and Other Sites. Clin. Cancer Res. 2011, 17, 3933-3942.

100. Xiao, W.; Du, N.; Huang, T.; Guo, J.; Mo, X.; Yuan, T.; Chen, Y.; Ye, T.; Xu, C.; Wang, W.; et al. TP53 Mutation as Potential Negative Predictor for Response of Anti-CTLA-4 Therapy in Metastatic Melanoma. EBioMedicine 2018, 32, 119-124. [CrossRef]

101. Ablain, J.; Liu, S.; Moriceau, G.; Lo, R.S.; Zon, L.I. SPRED1 Deletion Confers Resistance to MAPK Inhibition in Melanoma. J. Exp. Med. 2021, 218. [CrossRef]

102. Qadeer, Z.A.; Harcharik, S.; Valle-Garcia, D.; Chen, C.; Birge, M.B.; Vardabasso, C.; Duarte, L.F.; Bernstein, E. Decreased Expression of the Chromatin Remodeler ATRX Associates with Melanoma Progression. J. Investig. Dermatol. 2014, 134, 1768-1772. [CrossRef]

103. Piura, B. Management of Primary Melanoma of the Female Urogenital Tract. Lancet Oncol. 2008, 9, 973-981. [CrossRef]

104. Breslow, A. Thickness, Cross-Sectional Areas and Depth of Invasion in the Prognosis of Cutaneous Melanoma. Ann. Surg. 1970, 172, 902-908. [CrossRef]

105. Clark, W.H., Jr.; From, L.; Bernardino, E.A.; Mihm, M.C. The Histogenesis and Biologic Behavior of Primary Human Malignant Melanomas of the Skin. Cancer Res. 1969, 29, 705-727.

106. Chung, A.F.; Woodruff, J.M.; Lewis, J.L., Jr. Malignant Melanoma of the Vulva: A Report of 44 Cases. Obstet. Gynecol. 1975, 45, 638-646. [CrossRef]

107. Leitao, M.M., Jr. Management of Vulvar and Vaginal Melanomas: Current and Future Strategies. Am. Soc. Clin. Oncol. Educ. Book 2014, e277-e281. [CrossRef]

108. Treatment of Vulvar Melanoma. Available online: https://www.cancer.org/cancer/vulvar-cancer/treating/vulvar-melanoma. html (accessed on 26 April 2021).

109. Gadducci, A.; Carinelli, S.; Guerrieri, M.E.; Aletti, G.D. Melanoma of the Lower Genital Tract: Prognostic Factors and Treatment Modalities. Gynecol. Oncol. 2018, 150, 180-189. [CrossRef] [PubMed] 
110. Albert, A.; Lee, A.; Allbright, R.; Vijayakumar, S. Vulvar Melanoma: An Analysis of Prognostic Factors and Treatment Patterns. J. Gynecol. Oncol. 2020, 31, e66. [CrossRef]

111. Cinotti, E.; Chevallier, J.; Labeille, B.; Cambazard, F.; Thomas, L.; Balme, B.; Leccia, M.T.; D’Incan, M.; Vercherin, P.; Douchet, C.; et al. Mucosal Melanoma: Clinical, Histological and c-Kit Gene Mutational Profile of 86 French Cases. J. Eur. Acad. Dermatol. Venereol. 2017, 31, 1834-1840. [CrossRef] [PubMed]

112. Domingues, B.; Lopes, J.M.; Soares, P.; Pópulo, H. Melanoma Treatment in Review. ImmunoTargets Ther. 2018, 7, 35-49. [CrossRef]

113. Janco, J.M.; Markovic, S.N.; Weaver, A.L.; Cliby, W.A. Vulvar and Vaginal Melanoma: Case Series and Review of Current Management Options Including Neoadjuvant Chemotherapy. Gynecol. Oncol. 2013, 129, 533-537. [CrossRef]

114. Tcheung, W.J.; Selim, M.A.; Herndon, J.E., 2nd; Abernethy, A.P.; Nelson, K.C. Clinicopathologic Study of 85 Cases of Melanoma of the Female Genitalia. J. Am. Acad. Dermatol. 2012, 67, 598-605. [CrossRef] [PubMed]

115. Handolias, D.; Hamilton, A.L.; Salemi, R.; Tan, A.; Moodie, K.; Kerr, L.; Dobrovic, A.; McArthur, G.A. Clinical Responses Observed with Imatinib or Sorafenib in Melanoma Patients Expressing Mutations in KIT. Br. J. Cancer 2010, 102, 1219-1223. [CrossRef]

116. Hodi, F.S.; O’Day, S.J.; McDermott, D.F.; Weber, R.W.; Sosman, J.A.; Haanen, J.B.; Gonzalez, R.; Robert, C.; Schadendorf, D.; Hassel, J.C.; et al. Improved Survival with Ipilimumab in Patients with Metastatic Melanoma. N. Engl. J. Med. 2010, 363, 711-723. [CrossRef]

117. Cocorocchio, E.; Pala, L.; Conforti, F.; Guerini-Rocco, E.; De Pas, T.; Ferrucci, P.F. Successful Treatment with Avapritinib in Patient with Mucosal Metastatic Melanoma. Ther. Adv. Med. Oncol. 2020, 12, 1758835920946158. [CrossRef]

118. Brand, E.; Fu, Y.S.; Lagasse, L.D.; Berek, J.S. Vulvovaginal Melanoma: Report of Seven Cases and Literature Review. Gynecol. Oncol. 1989, 33, 54-60. [CrossRef]

119. Landthaler, M.; Braun-Falco, O.; Richter, K.; Baltzwr, J.; Zander, J. Maligne Melanome Der Vulva. DMW 1985, 110, 789-794. [CrossRef] [PubMed]

120. Lotem, M.; Anteby, S.; Peretz, T.; Ingber, A.; Avinoach, I.; Prus, D. Mucosal Melanoma of the Female Genital Tract Is a Multifocal Disorder. Gynecol. Oncol. 2003, 88, 45-50. [CrossRef] [PubMed]

121. Tsvetkov, C.; Gorchev, G.; Tomov, S.; Hinkova, N.; Nikolova, M.; Veselinova, T. Primary malignant melanoma of the vagina and treatment options: A case report. Akush. Ginekol. 2014, 53, 35-40.

122. Irvin, W.P., Jr.; Legallo, R.L.; Stoler, M.H.; Rice, L.W.; Taylor, P.T., Jr.; Andersen, W.A. Vulvar Melanoma: A Retrospective Analysis and Literature Review. Gynecol. Oncol. 2001, 83, 457-465. [CrossRef]

123. Schiavone, M.B.; Broach, V.; Shoushtari, A.N.; Carvajal, R.D.; Alektiar, K.; Kollmeier, M.A.; Abu-Rustum, N.R.; Leitao, M.M., Jr. Combined Immunotherapy and Radiation for Treatment of Mucosal Melanomas of the Lower Genital Tract. Gynecol. Oncol. Rep. 2016, 16, 42-46. [CrossRef] [PubMed]

124. González-Bosquet, J.; García Jiménez, A.; Gil Moreno, A.; Xercavins, J. Malignant Vulvo-Vaginal Melanoma: A Report of 7 Cases. Eur. J. Gynaecol. Oncol. 1997, 18, 63-67. 